\title{
ON A MORE ACCURATE MULTIDIMENSIONAL HILBERT-TYPE INEQUALITY WITH PARAMETERS
}

\author{
BICHENG YANG
}

Abstract. In this paper, by using the way of weight coefficients and technique of real analysis and complex analysis, a more accurate multidimensional discrete Hilbert-type inequality with a best possible constant factor and some parameters is given. The equivalent form, the operator expression with the norm are also considered.

Mathematics subject classification (2010): 26D15, 47A07.

Keywords and phrases: Hilbert-type inequality, weight coefficient, equivalent form, operator, norm.

\section{REFERENCES}

[1] G. H. Hardy, J. E. Littlewoog, G. Pólya, Inequalities, Cambridge University Press, Cambridge, 1934.

[2] D. S. Mitrinović, J. E. PeČARIĆ, A. M. FinK, Inequalities involving functions and their integrals and derivatives, Kluwer Acaremic Publishers, Boston, 1991.

[3] B. Yang, Hilbert-type integral inequalities, Bentham Science Publishers Ltd., Dubai, 2009.

[4] B. Yang, Discrete Hilbert-type inequalities, Bentham Science Publishers Ltd., Dubai, 2011.

[5] B. YANG, On Hilbert's integral inequality, Journal of Mathematical Analysis and Applications, 220 (1998), 778-785.

[6] B. YANG, The norm of operator and Hilbert-type inequalities, Science Press, Beijin, 2009 (China).

[7] B. YANG, Two types of multiple half-discrete Hilbert-type inequalities, Lambert Academic Publishing, Berlin, 2012.

[8] B. Yang, I. Brnetić, M. Krnić, J. E. PeČArić, Generalization of Hilbert and Hardy-Hilbert integral inequalities, Math. Ineq. and Appl., 8, 2 (2005), 259-272.

[9] M. Krnić, J. E. PeČARIĆ, Hilbert's inequalities and their reverses, Publ. Math. Debrecen, 67, 3-4 (2005), 315-331.

[10] B. YANG, TH. M. RASSIAS, On the way of weight coefficient and research for Hilbert-type inequalities, Math. Ineq. Appl., 6, 4 (2003), 625-658.

[11] B. YANG, TH. M. RASSIAS, On a Hilbert-type integral inequality in the subinterval and its operator expression, Banach J. Math. Anal., 4, 2 (2010), 100-110.

[12] L. AZAR, On some extensions of Hardy-Hilbert's inequality and Applications, Journal of Inequalities and Applications, 2009, no. 546829.

[13] B. Arpad, O. Hoonghong, Best constant for certain multi linear integral operator, Journal of Inequalities and Applications, 2006, no. 28582.

[14] J.' Kunng, L. Debnath, On Hilbert's type inequalities on the weighted Orlicz spaces, Pacific J. Appl. Math., 1, 1 (2007), 95-103.

[15] W. ZHONG, The Hilbert-type integral inequality with a homogeneous kernel of Lambda-degree, Journal of Inequalities and Applications, 2008, no. 917392.

[16] Y. Hong, On Hardy-Hilbert integral inequalities with some parameters, J. Ineq. in Pure \& Applied Math., 6, 4 (2005) Art. 92, 1-10.

[17] W. Zhong, B. Yang, On multiple Hardy-Hilbert's integral inequality with kernel, Journal of Inequalities and Applications, Vol. 2007, Art. ID 27962, 17 pages, doi: 10.1155/ 2007/27.

[18] B. YANG, M. KRnIĆ, On the Norm of a Mult-dimensional Hilbert-type Operator, Sarajevo Journal of Mathematics, 7, 20 (2011), 223-243. 
[19] M. KRnić, J. E. PeČARIĆ, P. Vuković, On some higher-dimensional Hilbert's and Hardy-Hilbert's type integral inequalities with parameters, Math. Inequal. Appl., 11 (2008), 701-716.

[20] M. Krnić, P. Vuković, On a multidimensional version of the Hilbert-type inequality, Analysis Mathematica, 38 (2012), 291-303.

[21] M. TH. RASSiAs, B. YANG, A multidimensional half-discrete Hilbert-type inequality and the Riemann zeta function, Applied Mathematics and Computation, 225 (2013), 263-277.

[22] Y. LI, B. HE, On inequalities of Hilbert's type, Bulletin of the Australian Mathematical Society, 76, 1 (2007), 1-13.

[23] B. YANG, A mixed Hilbert-type inequality with a best constant factor, International Journal of Pure and Applied Mathematics, 20, 3 (2005), 319-328.

[24] B. YANG, A half-discrete Hilbert-type inequality, Journal of Guangdong University of Education, 31, 3 (2011), 1-7.

[25] W. ZHONG, A mixed Hilbert-type inequality and its equivalent forms, Journal of Guangdong University of Education, 31, 5 (2011), 18-22.

[26] W. ZHONG, A half discrete Hilbert-type inequality and its equivalent forms, Journal of Guangdong University of Education, 32, 5 (2012), 8-12.

[27] J. ZHONG, B. YANG, On an extension of a more accurate Hilbert-type inequality, Journal of Zhejiang University (Science Edition), 35, 2 (2008), 121-124.

[28] J. ZHONG, Two classes of half-discrete reverse Hilbert-type inequalities with a non-homogeneous kernel, Journal of Guangdong University of Education, 32, 5 (2012), 11-20.

[29] W. ZHONG, B. YANG, A best extension of Hilbert inequality involving several parameters, Journal of Jinan University (Natural Science), 28, 1 (2007), 20-23.

[30] W. ZhONG, B. YANG, A reverse Hilbert's type integral inequality with some parameters and the equivalent forms, Pure and Applied Mathematics, 24, 2 (2008), 401-407.

[31] M. TH. Rassias, B. YAnG, On half-discrete Hilbert's inequality, Applied Mathematics and Computation, 220 (2013), 75-93.

[32] W. ZhONG, B. YANG, On multiple Hardy-Hilbert's integral inequality with kernel, Journal of Inequalities and Applications, Vol. 2007, Art. ID 27962, 17 pages, doi: 10.1155/2007/27.

[33] B. YANG, Q. CHEN, A half-discrete Hilbert-type inequality with a homogeneous kernel and an extension, Journal of Inequalities and Applications, 124 (2011), doi:10.1186/1029-242X-2011-124.

[34] B. YANG, A half-discrete Hilbert-type inequality with a non-homogeneous kernel and two variables, Mediterranean Journal of Methematics, 10 (2013), 677-692.

[35] B. YANG, Hilbert-type integral operators: norms and inequalities (In Chapter 42 of "Nonlinear Analysis, stability, approximation, and inequalities" (P. M. Paralos et al.)), Springer, New York, 771-859, 2012.

[36] Y. Pan, H. Wang, F. Wang, On complex functions, Science Press, Beijing, 2006 (China).

[37] J. KuAng, Applied inequalities, Shangdong Science Technic Press, Jinan, 2004 (China). 